\title{
Pathogenicity of phylogenetic species in the Fusarium graminearum complex on soybean seedlings in Argentina
}

\author{
Germán G. Barros • María S. Alaniz Zanon • \\ María L. Chiotta • María M. Reynoso • \\ María M. Scandiani • Sofía N. Chulze
}

Accepted: 28 October 2013 /Published online: 22 November 2013

(C) KNPV 2013

\begin{abstract}
Soybean (Glycine max L.) is one of the main crops in Argentina. Most of the studies of pathogenicity in the Fusarium graminearum complex have focused on strains isolated from wheat and maize, and there is little information on strains isolated from soybean. Our objective in the present study was to compare the pathogenicity among soybean isolates of different phylogenetic species within the Fusarium graminearum complex on soybean seedlings under controlled conditions. Six strains representing three different phylogenetic species $(F$. graminearum, F. meridionale and $F$. cortaderiae) were identified by partial sequencing of the Translation Elongation Factor $-1 \alpha$ gene $(T E F-1)$ and evaluated for pathogenicity. All six strains reduced emergence, mainly by causing pre-emergence damping-off, seedling height and root dry weight and produced abnormal seedlings. The mean disease severity averaged across all isolates was approximately 3.0 in a $0-4$ rating scale where $0=$ healthy seedling and $4=$ dead seedling. Significant differences in pathogenicity were observed among $F$. graminearum, $F$. meridionale and F. cortaderiae. These results are consistent with the hypothesis that different phylogenetic
\end{abstract}

G. G. Barros • M. S. A. Zanon • M. L. Chiotta •

M. M. Reynoso $\cdot$ S. N. Chulze $(\bowtie)$

Departamento de Microbiología e Inmunología, Facultad de Ciencias Exactas Físico Químicas y Naturales, Universidad Nacional de Río Cuarto, Ruta Nacional Nº 36 Km 601, 5800 Río Cuarto, Córdoba, Argentina

e-mail: schulze@exa.unrc.edu.ar

M. M. Scandiani

Laboratorio Agrícola Río Paraná, San Pedro,

Buenos Aires, Argentina species within the Fusarium graminearum complex isolated from soybean are pathogenic under controlled conditions to soybean seedlings in Argentina. The present study demonstrates for the first time the pathogenic effect of $F$. meridionale on soybean in Argentina.

Keywords Fusarium graminearum - F. meridionale · F. cortaderiae - Elongation factor 1- $\alpha$. Glycine max L . Pathogenicity

The Fusarium graminearum complex is composed of at least sixteen lineages (O’Donnell et al. 2000, 2004, 2008; Sarver et al. 2011; Starkey et al. 2007; Yli-Mattila et al. 2009) most of which have now been described as phylogenetic species: $F$. austroamericanum, F. meridionale, $F$. boothii, F. mesoamericanum, F. acacia-mearnsii, $F$. asiaticum, F. graminearum sensu stricto, F. cortaderiae, F. brasilicum, F. aethiopicum, F. gerlachii, F. vorosii and $F$. ussuarianum. Species within the complex, mainly $F$. graminearum, are important pathogens of wheat and maize in the subtropical and temperate regions of Argentina (Chulze et al. 1996).

The species composition of the $F$. graminearum complex population appears to be host and location dependent. In Argentina, F. graminearum sensu stricto is the only phylogenetic species isolated from wheat in different subregions of the main wheat production area (Alvarez et al. 2011; Ramirez et al. 2007), but F. meridionale and $F$. boothii may be the most important on maize (Sampietro et al. 2011). These could be interpreted as differences in host preference between 
lineages within the $F$. graminearum complex. In a previous study, molecular markers such as amplified fragment length polymorphism (AFLP) were used to characterize the $F$. graminearum complex population isolated from one soybean field located at Córdoba Province, Argentina. The results demonstrated the presence of at least two phylogenetic species, F. graminearum sensu stricto and F. meridionale (Barros et al. 2012).

Disease reports of the pathogenicity of strains from the $F$. graminearum complex towards soybean are contradictory. In some cases these strains were considered to be secondary colonizers of soybean seeds previously damaged by other fungi or by freezing (Jacobsen et al. 1995; Osorio and McGee 1992; Wicklow et al. 1987), while in others cases the strains were considered to be nonpathogenic to soybean (García-Romera et al. 1998; Miller et al. 1998). These arguments were based on failed attempts to complete Koch's postulates, following direct inoculations of seedling hypocotyls or applications of spore suspensions of F. graminearum to flowers (Fernandez and Fernandes 1990). At present $F$. graminearum is recognized as a primary pathogen of soybean in several countries in the American continents (Broders et al. 2007; Diaz Arias et al. 2013; Ellis et al. 2011; Martinelli et al. 2004; Pioli et al. 2004; Xue et al. 2007).

Soybean (Glycine max L. Merr.) is the most important field crop in Argentina, where the planted area has reached $11,000,000$ ha with annual production approximately 35,000,000 metric tonnes (MAGPyA (http:// www.sagyp.mecon.gov.ar)). Members of the $F$. graminearum complex frequently are recovered from flowers, pods and soybean seeds and deoxynivalenol can be detected at significant levels in soybean meal (Barros et al. 2011; Peruzzo et al. 2011) and soybean seed (Barros et al. 2012). During the 1990s, agriculture changed significantly in Argentina, e.g. the adoption of transgenic crops such as soybean, maize and cotton under no-till conditions system (Pengue 2005). Adoption of conservation tillage may be the most important of these system changes as members of the $F$. graminearum can readily colonize crop debris of wheat, corn and soybean (Baird et al. 1997; Palazzini et al. 2012). Soybean is often part of a crop rotation with wheat and other cereal crops in Argentina therefore, members of the $F$. graminearum complex that colonize soybean debris could provide inoculum for wheat and maize infections, and those that colonize wheat and maize debris could provide inoculum for soybean infections.
Pioli et al. (2004) first described the pathogenicity of F. graminearum to soybean in Argentina. However, this study did not distinguish phylogenetic species within the $F$. graminearum complex. Due to the economic value of soybean and the increase in production area in Argentina, the role of members of the different lineages in the F. graminearum complex and their importance as potential soybean pathogens needs to be determined. The objective of this study was to compare the pathogenicity of soybean isolates from different phylogenetic species within the $F$. graminearum complex towards soybean seedlings under controlled conditions.

\section{Materials and methods}

Six isolates characterized morphologically as strains belonging to the F. graminearum complex (Leslie and Summerell 2006) were included in the study. These isolates were collected in a previous study during the 2007/2008 harvest season from an experimental field at the National University of Río Cuarto, Córdoba, Argentina (Barros et al. 2012). All isolates were maintained as cultures on Synthetisher Nährstoffarmer Agar (SNA) (Nirenberg 1976) slants at $4{ }^{\circ} \mathrm{C}$ and as spore suspensions in glycerol $20 \%(\mathrm{w} / \mathrm{v})$ at $-80{ }^{\circ} \mathrm{C}$.

Strains were grown in complete medium (CM) (Leslie and Summerell 2006) and incubated on an orbital shaker ( $150 \mathrm{rpm})$ for at least 3 days at $25 \pm 1{ }^{\circ} \mathrm{C}$. The resulting mycelia were harvested by filtration through non-gauze milk filters (Ken AG, Ashland, Ohio). Excess water was removed by blotting mycelia between clean paper towels, and dried mycelia were stored frozen at $-20{ }^{\circ} \mathrm{C}$. DNA was extracted with a cetyltrimethylammnonium bromide (CTAB) method (Leslie and Summerell 2006).

Analyses of the partial sequence of the translation elongation factor- $1 \alpha$ gene (TEF-1 $\alpha$ ), were made following PCR amplification with the primers described by O'Donnell et al. (2000, 2004). PCR experiments were conducted with 10-20 ng of fungal DNA in a total volume of $20 \mu \mathrm{l}$ of $1 \times$ reaction buffer containing $1.5 \mathrm{mM} \mathrm{MgCl}_{2}, 0.5 \mathrm{U}$ Taq DNA polymerase (Promega), $0.2 \mathrm{mM}$ dNTPs and $0.5 \mu \mathrm{M}$ of each TEF primer (E1 5'-ATGGGTAAGGAGGACAAGAC-3', E2 5'-GGAAGTACCAGTGATCATGTT-3'). A negative control, containing all reagents and primers but no fungal DNA, was included in every set of reactions. PCR was conducted in a PTC-2000 Thermal Cycler (MJ 
Research Inc., Watertown, MA) and the conditions were: $94{ }^{\circ} \mathrm{C}$ for $1 \mathrm{~min}$, then 31 cycles of $94{ }^{\circ} \mathrm{C}$ for $30 \mathrm{~s}, 56^{\circ} \mathrm{C}$ for $45 \mathrm{~s}$ and $72{ }^{\circ} \mathrm{C}$ for $1 \mathrm{~min}$, followed by $72{ }^{\circ} \mathrm{C}$ for $5 \mathrm{~min}$ and a $4{ }^{\circ} \mathrm{C}$. PCR products were separated by electrophoresis through $2 \%(\mathrm{w} / \mathrm{w})$ agarose gels to confirm that a $\sim 700 \mathrm{bp}$ fragment was amplified for $T E F-1 \alpha$. Fragments were purified by filtration through DNA Wizard Clean-Up Kit (Promega, Madison, WI). Sequencing of both strands was performed with an ABI 3130XL DNA Sequencer (Applied Biosystems) and each sequence was then aligned with ClustalW (Thompson et al. 1994), as implemented in the program BioEdit version 7.0.9.0 (Hall 1999). All isolates were identified as members of the $F$. graminearum complex by conducting BLAST searches of GenBank with partial translation elongation factor sequences as the query.

Six isolates representing three different species within the F. graminearum complex were used in greenhouse and rolled-towel pathogenicity assays. Both the greenhouse and rolled towel experiments were repeated twice. In the greenhouse assays, inoculum was prepared by growing each isolate on potato dextrose agar (PDA) amended with streptomycin $\left(100 \mathrm{mg} \mathrm{l}^{-1}\right)$ (Singleton et al. 1993) for 1 week at $25{ }^{\circ} \mathrm{C}$ in the dark. A $500 \mathrm{ml}$ flask containing $125 \mathrm{~g}$ of Czapek Dox-bran-vermiculite medium (4:10:10; v/w/w), was autoclaved for $30 \mathrm{~min}$ at $121{ }^{\circ} \mathrm{C}$ and allowed to cool. Five, $5 \mathrm{~mm}$ diameter plugs from the culture on PDA were added to the Czapek Doxbran-vermiculite medium; the medium was incubated at $25{ }^{\circ} \mathrm{C}$ in the dark for 2 weeks and shaken daily. A nursery substrate (Grow Mix, Multipro, Terrafertil S.A., Buenos Aires, Argentina) was infested by adding $7 \mathrm{~g}$ of inoculum of each isolate to a litre of potting mix. Inoculated soil was dispersed into $12-\mathrm{cm}$ diameter plastic pots. Ten seeds of soybean cultivar DM 4670 RG (genetically modified for tolerance to glyphosate, maturity group IV) were planted to a depth of 3-4 cm, watered to saturation after planting and maintained at near field capacity throughout the study. Following seedling, pots were incubated in a chamber at $25 \pm 2{ }^{\circ} \mathrm{C}$ for 5 days using a randomized complete block design, and then placed on a greenhouse bench and grown under natural photoperiod at $25 \pm 3{ }^{\circ} \mathrm{C}$ for 12 days. Ten soybean seeds per pot were sowed, with replications of four pots per treatment arranged in a randomized complete block design. Non-inoculated plants served as a negative control. These control pots contained the inoculum substrate at the same rate but without pathogen. Also, an absolute check without the inoculum substrate was sowed (data was not included). At the end of the experiments, each treatment was assessed for percentage of emerged seedlings, percentage of abnormal seedlings (mainly classified in this way due to weak seedlings and root and cotyledon necrotic lesions), percentage of crown or basal stem rot (as can be more severe than root lesions and kills the plants) and shoot and root dry weight.

The evaluation of seedlings height and disease severity was performed in a rolled-towel assay described by Xue et al. (2007). Soybean seeds (cultivar DM 4670 RG) were surface disinfected by soaking in $0.5 \%(\mathrm{v} / \mathrm{v})$ $\mathrm{NaOCl}$ for $30 \mathrm{~s}$ and rinsed twice in sterile distilled water. Then disinfected seeds were spread evenly on two layers of sterilized paper towels moistened with $50 \mathrm{ml}$ of sterilized water and covered with two layers of paper towels in plastic containers to allow the germination. Containers were covered with plastic lids and kept in darkness at $24{ }^{\circ} \mathrm{C}$ for $3-4$ days until plants were at the early VE growth stage and root hairs were visible. Visually healthy seedlings were selected and disinfected as described above. Seedlings were infested by transferring agar plugs ( $5 \mathrm{~mm}$ in diameter) with a sterilized metal needle from 7-day-old fungal cultures to the root-hair zone, about $1.5 \mathrm{~cm}$ behind the primary-root tip. Control plants were inoculated with agar plugs from sterile PDA. Inoculated plants were each placed vertically on precut covering sheets consisting of two layers of the sterilized paper tissue laid on top of an aluminum foil sheet. The entire root along with the attached agar disc of an individual plant was then covered by folding the covering sheets in the middle. A growth unit for each plant was formed by further folding the covering sheets on the opening side. The growth units were placed in plastic trays containing sterilized distilled water at a depth of $0.5 \mathrm{~cm}$. The open top of the growth unit allowed for plant growth and the open bottom for root development and water absorption. The aluminum foil sheet was used to separate each unit and for moisture retention. The trays were placed in a growth chamber operated at $24{ }^{\circ} \mathrm{C}$ with a $16 \mathrm{~h}$ photoperiod of fluorescent light. The water level in the tray was checked daily and the water was added as needed. Ten days after inoculation, plants were removed from the growth unit and visually assessed for root-rot severity. Symptoms were rated using a 0-4 scale (Fig. 1): 0, no visible disease symptoms; 1 , lesion visible, but infection confined to the inoculation site, with normal seedling growth; 2, 


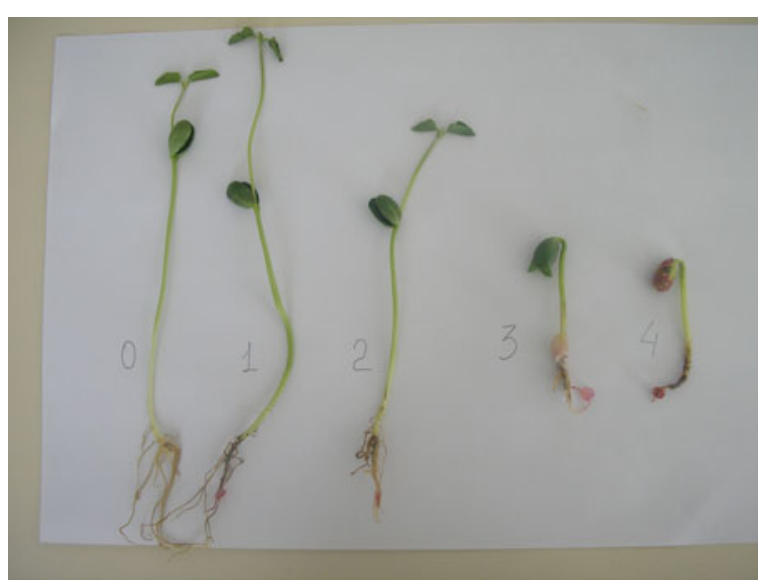

Fig. 1 Ordinal scale used to evaluate disease severity caused by Fusarium meridionale: 0, no visible disease symptoms; 1, lesion visible, but infection confined to the inoculation site with normal seedling growth; 2 , lesion size extended and plant growth retarded; 3 , infection of the entire root, and plant growth halted; 4 , massive infection of the entire root resulting in plant death

lesion size extended and the plant growth retarded; 3, infection of the entire root, and the plant growth halted; and 4 , massive infection of the entire root resulting in plant death.

Data from the two independent experiments were combined and analyzed as one. Data on root-rot severity often were not normally distributed and were analyzed by using the nonparametric Kruskal-Wallis test and then by Dunn's nonparametric multiple comparisons test at a probability level of $p<0.05$. Percentage of seedling emergence, abnormal seedlings and crown rot were square root transformed to reduce variance. The remaining dependent variables (shoot dry weight/plant, root dry weight/plant and seedling height) were subjected to an analysis of variance (ANOVA) without further transformation. Treatment means of the transformed and untransformed data were separated by Fisher's least significant difference (LSD) test at a probability level of $p<0.05$ (SAS 1998).

\section{Results}

The partial TEF1- $\alpha$ gene sequence of F5050 and F5051 isolates had a high match with $F$. graminearum sensu stricto, F5030, F5043 and F5048 sequences corresponded with $F$. meridionale and F5036 corresponded with $F$. cortaderiae (Table 1). TEF1- $\alpha$ gene sequence of isolates used in the present study were compared with the sequences depicted by O'Donnell et al. (2000; 2004), Starkey et al. (2007) and Ward et al. (2008).

In the greenhouse assays, the isolates caused variable changes in the growth parameters evaluated in the inoculated plants whereas the un-inoculated plants remained healthy throughout the experiments (Table 2). All of the isolates significantly reduced seedling emergence, mainly by causing pre-emergence damping-off. The percentage of abnormal seedlings observed ranged from 12 to $27 \%$. The main symptoms observed were seed decay, weak seedlings and necrotic lesions on cotyledons. Plants inoculated with $F$. cortaderiae F5036 and $F$. graminearum F5051 had higher levels of crown rot, while plants inoculated with F. meridionale F5030 had no crown rot symptoms. All isolates significantly reduced $(p<0.05)$ root dry weight relative to uninoculated seedlings; however only one isolate had a significant decrease in shoot dry weight.

In the rolled-towel assays the seedling height of the inoculated seedlings was reduced by 39 and $57 \%$ relative to the control seedlings. All isolates caused root rot and there were significant differences in disease severity among $F$. graminearum, F. meridionale and $F$. cortaderiae isolates were observed in both experiments. The mean

Table 1 Origin of isolates in the Fusarium graminearum complex

\begin{tabular}{llllll}
\hline Isolate & Host & Year & Location & TEF1- $\alpha$ identification (\%) & Genbank accession number \\
\hline F5030 & Soybean flower & 2008 & Río Cuarto (Córdoba) & F. meriodionale (100 \%) & JQ740897 \\
F5048 & Soybean pod & 2008 & Río Cuarto (Córdoba) & F. meriodionale (99 \%) & JQ740896 \\
F5043 & Soybean seed & 2008 & Río Cuarto (Córdoba) & F. meridionale (99 \%) & JQ740895 \\
F5036 & Soybean seed & 2008 & Río Cuarto (Córdoba) & F. cortaderiae (99\%) & JQ740894 \\
F5050 & Soybean pod & 2008 & Río Cuarto (Córdoba) & F. graminearum (99\%) & JQ740892 \\
F5051 & Soybean flower & 2008 & Río Cuarto (Córdoba) & F. graminearum (100\%) & JQ740893 \\
\hline
\end{tabular}

\footnotetext{
${ }^{\text {a }}$ Percentage of maximum identity of TEF1- $\alpha$ sequence according to Blast database
} 


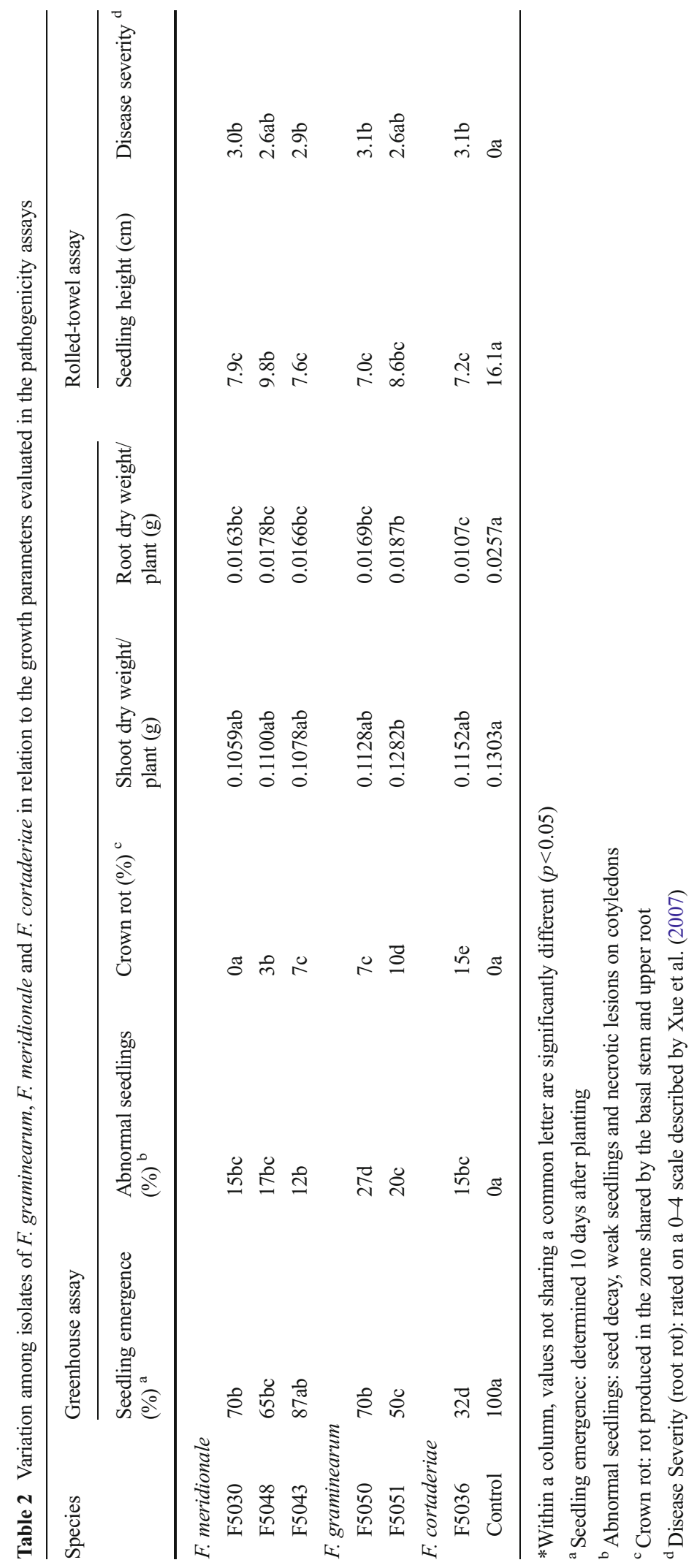


disease severity averaged over the isolates evaluated in this study was approximately 3 . Root-rot symptoms first appeared as water-soaked lesions at the point of inoculation, and were followed by a pink discolouration that spread, both up and down the root (Fig. 2).

\section{Discussion}

Most studies of pathogenicity of members of $F$. graminearum complex have focused on strains isolated from wheat, barley and maize, and there is little information on strains isolated from soybean. F. graminearum sensu stricto is the only phylogenetic species in the $F$. graminearum complex isolated from wheat, while $F$. meridionale, F. boothii and F. graminearum sensu stricto all have been recovered from corn in Argentina (Alvarez et al. 2011; Ramirez et al. 2007; Sampietro et al. 2010, 2011). F. graminearum sensu stricto and F. meridionale were isolated from soybean in Argentina (Barros et al. 2012). The translation elongation factor $1-\alpha$ (TEF1- $\alpha$ ) gene occurs consistently as a single copy in Fusarium, and is highly polymorphic among closely related species (Rahjoo et al. 2008). We used partial TEF1- $\alpha$ gene sequences to assign members of the $F$. graminearum complex to a phylogenetic species. Results of a survey demonstrated that $F$. cortaderiae was recovered in low frequencies from soybean (data unpublished). For this reason, one F. cortaderiae isolate was included in this study together with the two phylogenetic species more prevalent in soybean in Argentina.

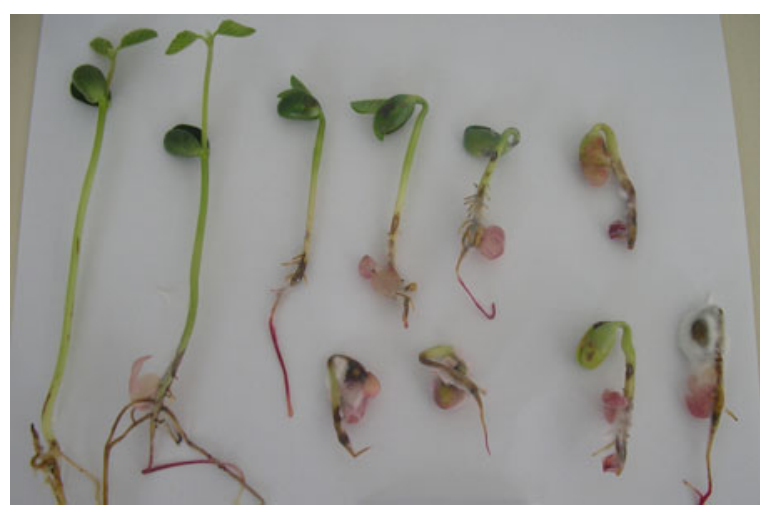

Fig. 2 Seedlings with different symptoms (infection confined to inoculation site, normal seedling growth to highly affected plants, and dead plants with entire root, cotyledons and first pair leaves rot) caused by $F$. meridionale F5030 isolate 10 days after inoculation
Several studies have reported that members of the $F$. graminearum complex are pathogenic to soybean cultivars (Broders et al. 2007; Diaz Arias et al. 2013; Ellis et al. 2011; Martinelli et al. 2004; Pioli et al. 2004; Xue et al. 2007). In Argentina, Pioli et al. (2004) have also observed a pathogenic association between $F$. graminearum strains and soybean plants. However, the strains were characterized using only morphological criteria, and the difficulties in the recognition of species within $F$. graminearum complex suggest that molecular tools are necessary to assign them at phylogenetic species level. Thus, although only a limited number of isolates from each fungal species were evaluated in the present study, this is the first report that demonstrates pathogenicity of $F$. meridionale on soybean seedlings in Argentina. As regard F. cortaderiae, only one isolate was evaluated and further studies are necessary to confirm the pathogenic effect.

All of the isolates evaluated in the present study caused root rot and significant difference in pathogenicity was observed among at the three species were observed. The mean disease severity among the six isolates was slightly above the average reported by Xue et al. (2007) for Canadian wheat isolates evaluated on different soybean cultivars. There could be selection pressure for highly aggressive $F$. graminearum isolates when soybean is used in rotation with small grains and corn. In this sense, Akinsanmi et al. (2007) demonstrated that growth on an alternative host plant can influence the aggressiveness of Fusarium graminearum on wheat spikes.

In Argentina, soybean often is used in rotation with wheat and other cereal crops in a reduced till or no-till system. Species within the $F$. graminearum complex can survive in crop residues left on the surface, increasing the inoculum density and providing an inoculum source for wheat or corn infections in subsequent year. Recently, an increase in stalk and basal root rot in corn caused by strains belonging to $F$. graminearum complex was reported in the Center South region of Córdoba Province (Marinelli et al. 2010). These findings could be related to the widespread adoption of conservation tillage as suggested by Munkvold (2003) and intensive soybean cultivation.

The results obtained in the present study are consistent with the hypothesis that different species within the F. graminearum complex isolated from soybean are pathogenic to soybean seedlings in Argentina. Further studies are underway to characterize the aggressiveness 
of strains with different mycotoxin chemotypes on soybean and the role that mycotoxins play in the virulence of strains of $F$. graminearum complex toward soybean.

Acknowledgments This work was supported by grants from Secretaría de Ciencia y Técnica, Universidad Nacional de Río Cuarto (SECyT-UNRC 2010-2012) and Agencia Nacional de Promoción Científica y Tecnológica (PICT 2457/11). Alaniz Zanon, M.S and Chiotta, M.L. are fellow of CONICET and Barros, G., Reynoso, M.M. and Chulze, S. are members of the Research Career of CONICET. The authors thank Dr. John Leslie for revision of the manuscript.

\section{References}

Akinsanmi, O. A., Chakraborty, S., Backhouse, D., \& Simpfendorfer, S. (2007). Passage through alternative hosts changes the fitness of Fusarium graminearum and Fusarium pseudograminearum. Environmental Microbiology, 9, 512520.

Alvarez, C. L., Somma, S., Proctor, R. H., Stea, G., Mulè, G., Logrieco, A., et al. (2011). Genetic diversity in Fusarium graminearum from a major wheat-producing region of Argentina. Toxins, 3, 1294-1309.

Baird, R. E., Mullinix, B. G., Perry, A. B., \& Lang, M. L. (1997). Diversity and longevity of the soybean debris mycobiota in a no-tillage system. Plant Disease, 81, 530-534.

Barros, G., Oviedo, M. S., Ramirez, M. L., \& Chulze, S. (2011). Safety aspects in soybean food and feed chains: Fungal and mycotoxins contamination. In N. Tzi-Bun (Ed.), Soybean biochemistry, chemistry and physiology (pp. 7-20). Rijeka: InTech-Open Access Publisher.

Barros, G., Alaniz Zanon, M. S., Abod, A., Oviedo, M. S., Ramirez, M. L., Reynoso, M. M., et al. (2012). Natural deoxynivalenol occurrence and genotype and chemotype determination of a field population of the Fusarium graminearum complex associated with soybean in Argentina. Food Additives and Contaminants, 29, 293-303.

Broders, K. D., Lipps, P. E., Paul, P. A., \& Dorrance, A. E. (2007). Evaluation of Fusarium graminearum associated with corn and soybean seed and seedling in Ohio. Plant Disease, 91, $1155-1160$.

Chulze, S., Ramirez, M. L., Farnochi, M. C., Pascale, M., Visconti, A., \& March, G. (1996). Fusarium and fumonisins occurrence in Argentinian corn at different ear maturity stages. Journal Agricultural and Food Chemistry, 44, 2797-2801.

Diaz Arias, M. M., Leandro, L. F., \& Munkvold, G. P. (2013). Aggressiveness of Fusarium species and impact of root infection on growth and yield of soybeans. Phytopathology, 103, 822-832.

Ellis, M. L., Broders, K. D., Paul, P. A., \& Dorrance, A. E. (2011). Infection of soybean seed by Fusarium graminearum and effect of seed treatments on disease under controlled conditions. Plant Disease, 95, 401-407.

Fernandez, M. R., \& Fernandes, J. M. C. (1990). Survival of wheat pathogens in wheat and soybean residues under conservation tillage systems in southern and central Brazil. Canadian Journal of Plant Pathology, 12, 289-294.

García-Romera, I., García-Garrido, J. M., Martin, J., Fracchia, S., Mujica, M. T., Godeas, A., et al. (1998). Interactions between saprophitic Fusarium strains and arbuscular mycorrhizas of soybean plants. Symbiosis, 24, 235-245.

Hall, T. A. (1999). BioEdit: a user-friendly biological sequence alignment editor and analysis program for Windows 95/98/ NT. Nucleic Acids Symposium, 41, 95-98.

Jacobsen, B. J., Harbin, K. S., Swanson, S. P., Lambert, R. J., Beasley, V. R., Sinclair, J. B., et al. (1995). Occurrence of fungi and mycotoxins associated with field mold damage soybeans in the Midwest. Plant Disease, 79, 86-88.

Leslie, J. F., \& Summerell, B. A. (2006). The Fusarium laboratory manual. Ames: Blackwell Professional.

Marinelli, A., Oddino, C., García, J., Tarditi, L., Ferrari, S., \& D’Eramo, L. et al. (2010). Podredumbre del tallo y raíz del maíz en la región centro sur de Córdoba. IX Congreso Nacional de Maíz. Simposio Nacional de Sorgo. 17-19 de Noviembre de 2010. Rosario, Argentina. pp. 22-24.

Martinelli, J. A., Bocchese, C. A. C., Xie, W., O’Donnell, K., \& Kistler, H. C. (2004). Soybean pod blight and root rot caused by lineages of Fusarium graminearum and the production of mycotoxins. Fitopatolia Brasileira, 29, 492-498.

Miller, J. D., Culley, J., Fraser, K., Hubbard, S., Meloche, F., Ouellet, T., et al. (1998). Effect of tillage practices on Fusarium head blight of wheat. Canadian Journal of Plant Pathology, 20, 95-103.

Munkvold, G. P. (2003). Cultural and genetic approaches to managing mycotoxins in maize. Annual Review of Phytopathology, 41, 99-116.

Nirenberg, H. I. (1976). Untersuchungen über die morphologische und biologisch Diffrenzieerum in der Fusarium Sekion Lisiola. Mitteilungen aus der Biologischen Bundesanstalt Für Land- und Forstwirtschaft, 169, 1-117.

O’Donnell, K., Kistler, H. C., Tacke, B. K., \& Casper, H. H. (2000). Gene genealogies reveal global phylogeographic structure and reproductive isolation among lineages of Fusarium graminearum, the fungus causing wheat scab. Proceedings of the National Academy of Sciences USA, 97, 7905-7910.

O’Donnell, K., Ward, T. J., Geiser, D. M., Kistler, H. C., \& Aoki, T. (2004). Genealogical concordance between the mating type locus and seven other nuclear genes supports formal recognition of nine phylogenetically distinct species within the Fusarium graminearum clade. Fungal Genetics and Biology, 41, 600-623.

O’Donnell, K., Ward, T. J., Aberra, D., Kistler, H. C., Aoki, T., Orwig, N. G., et al. (2008). Multilocus genotyping and molecular phylogenetics resolve a novel head blight pathogen within the Fusarium graminearum species complex from Ethiopia. Fungal Genetics and Biology, 45, 1514-1522.

Osorio, J. A., \& McGee, D. C. (1992). Effect of freezing damage on soybean seed mycoflora and germination. Plant Disease, 76, 879-882.

Palazzini, J. M., Groenenboom-de Haas, B. H., Torres, A. M., Köhl, J., \& Chulze, S. N. (2012). Biocontrol and population dynamics of Fusarium spp. on wheat stubble in Argentina. Plant Pathology. doi:10.1111/j.1365-3059.2012.02686.x.

Pengue, W. (2005). Transgenic crops in Argentina: the ecological and social debt. Bulletin of Science Technology Society, 25, 314-322. 
Peruzzo, A., Pioli, R., Montiel, C., Lurá, M. C. \& Gonzalez, A. M. (2011). Transmission de deoxinivalenol a la harina de soja por infecciones de Fusarium graminearum en invernadero. V Congreso de la soja del Mercosur. 14-16 de septiembre. Rosario, Argentina. pp. 1-4

Pioli, R. N., Mozzoni, L., \& Morandi, E. N. (2004). First report of pathogenic association between Fusarium graminearum and soybean. Plant Disease, 88, 220.

Rahjoo, V., Zad, J., Javan-Nikkhah, M., Mirzadi Gohari, A., Okhovvat, S. M., Bihamta, M. R., et al. (2008). Morphological and molecular identification of Fusarium isolated from maize ears in Iran. Journal of Plant Pathology, 90, 463-468.

Ramirez, M. L., Reynoso, M. M., Farnochi, M. C., Torres, A. M., Leslie, J. F., \& Chulze, S. N. (2007). Population genetic structure of Gibberella zeae isolated from wheat in Argentina. Food Additives and Contaminants, 24, 1115-1120.

Sampietro, D. A., Marín, P., Iglesias, J., Presello, D. A., Vattuone, M. A., Catalan, C. A. N., et al. (2010). A molecular based strategy for rapid diagnosis of toxigenic Fusarium species associated to cereal grains from Argentina. Fungal Biology, $114,74-81$.

Sampietro, D. A., Díaz, C. G., Gonzalez, V., Vattuone, M. A., Ploper, L. D., Catalan, C. A., et al. (2011). Species diversity and toxigenic potential of Fusarium graminearum complex isolates from maize fields in northwest Argentina. International Journal of Food Microbiology, 145, 359-364.

Sarver, B., Ward, T., Gale, L., Broz, K., Kistler, H. C., Aoki, T., et al. (2011). Novel Fusarium head blight pathogens from Nepal and Louisiana revealed by multilocus genealogical concordance. Fungal Genetics and Biology, 48, 1096-1107.

SAS Institute. (1998). SAS user guide. Cary: SAS Institute Inc.
Singleton, L. L., Mihail, J. D., \& Rush, C. M. (1993). Methods for research on soilborne phytopahogenic fungi (2nd ed.). St. Paul: American Phytopathological Society.

Starkey, D. E., Ward, T. J., Aoki, T., Gale, L. R., Kistler, H. C., Geiser, D. M., et al. (2007). Global molecular surveillance reveals novel Fusarium head blight species and trichothecene toxin diversity. Fungal Genetics and Biology, 44, 11911204.

Thompson, J. D., Higgins, D. G., \& Gibson, T. J. (1994). CLUSTAL W: improving the sensitivity of progressive multiple sequence alignment through sequence weighting, positions-specific gap penalties and weight matrix choice. Nucleic Acids Research, 22, 4673-4680.

Ward, T. D., Clear, R. M., Rooney, A. P., O’Donnell, K., Gaba, D., Patrick, S., et al. (2008). An adaptive evolutionary shift in Fusarium head blight pathogen populations is driving the rapid spread of more toxigenic Fusarium graminearum in North America. Fungal Genetics and Biology, 45, 473-484.

Wicklow, D. T., Bennet, G. A., \& Shotwell, O. L. (1987). Secondary invasion of soybean by Fusarium graminearum and result in mycotoxin contamination. Plant Disease, 71, 1146.

Xue, A. G., Cober, E., Voldeng, H. D., Babcock, C., \& Clear, R. M. (2007). Evaluation of the pathogenicity of Fusarium graminearum and Fusarium pseudograminearum on soybean seedlings under controlled conditions. Canadian Journal of Plant Pathology, 29, 35-40.

Yli-Mattila, T., Gagkaeva, T., Ward, T. J., Aoki, T., Kistler, H. C., \& O'Donnell, K. (2009). A novel Asian clade within the Fusarium graminearum species complex includes a newly discovered cereal head blight pathogen from the Russian Far East. Mycologia, 101, 841-852. 